\title{
Pharmaceutical Waste Management An Overview
}

\author{
Atul Kadam ${ }^{1 *}$, Shitalkumar Patil ${ }^{1}$, Sachin Patil ${ }^{1}$, Anil Tumkur ${ }^{2}$ \\ 1'Department of Pharmaceutics, Ashokrao Mane College of Pharmacy, Peth Vadgaon, Kolhapur, INDIA. \\ ${ }^{2}$ Department of Pharmacy Practice, International Medical University, Kuala Lumpur, MALAYSIA.
}

\begin{abstract}
Introduction: Medication disposal is an alarming issue today and gaining more and more awareness from the healthcare professionals as well as consumers. Pharmacists have the potential to be on the forefront of this movement as a healthcare professionals and pharmacists are in an admirable position to educate patients about safe drug disposal. Proper patient counselling on safe medication disposal can make a significant difference to public health and the environment. The knowledge on method of disposal of unused medicines is equally important as that of consumption of medicines. Objective: This article aims to provide a background, the importance and significance of proper medication disposal, describe the correct methods to dispose of unwanted and expired medications. Method: The information about methods of proper disposal as well as consequence of improper disposal was collected by extensive literature survey of all available resources. Conclusion: Till date, researchers have acknowledged many human and veterinary pharmaceutical compounds at serious concentrations in drinking water resources and they are a major contributor to environmental pollution. Emphasis is also given on pharmacist role in proper disposal of unwanted and expired medicine makes a significant impact on the environment as well as it prevents accident, poisoning and intentional violence. So it will lead to the welfare of society and trudge towards goal of 2020 health for all.
\end{abstract}

Key words: Pharmaceutical Waste Management, Medication disposal, Patient education, Pollution.

\section{INTRODUCTION}

The pharmaceutical waste includes expired products, dispensed drugs that are unwanted or discontinued, and contaminated medications. When drugs are prescribed prophylactically or in response to an acute or chronic illness, only a portion of the active ingredient of the drug is metabolized. The non-metabolized parent compound, as well as the metabolites, enters the natural aquatic environment through waste discharges into receiving streams, which may pollute recreational lakes or even the intakes of drinking water treatment plants. ${ }^{1}$

Pharmaceutical compounds are designed to have biochemical activity in target organisms at relatively low concentrations. Therefore, at the low part-per-trillion levels, there is concern that some of these compounds could have an ecological and human health effect. Although physical and biological processes occurring in aquatic environments may cause attenuation of many pharmaceutical compounds, trace concentrations of human and veterinary pharmaceutical compounds and metabolites have been detected in Submitted date:04/12/2015 surface water, groundwater, and drinking water. ${ }^{2}$ According to a cross-sectional study conducted in the elderly population, high usage rate invariably corresponds to more drug wastage; study estimated that drug wastage accounted for $2-3 \%$ of all drug costs representing more than $\$ 1$ billion in drug wastage in the United States (US). ${ }^{3,4}$ In India according to the Central Pollution Control Board, registered healthcare facilities generate 4,057 tonnes of waste/day. ${ }^{5}$

An active pharmaceutical ingredient (API) is a chemical constituent having pharmacological activity and useful effect in the diagnosis, cure, mitigation, treatment, or prevention of disease or one that affects the structure or function of the body. ${ }^{6}$ Small molecule APIs are formulated into more than 20,000 parenteral, topical and oral drug prod-
Submitted date : 04/12/2015
Accepted date : 13/01/2016

DOI: 10.5530/ijopp.9.1.2

Address for correspondence: Mr. Atul Mansing Kadam, Department of Pharmaceutics, Ashokrao Mane College of Pharmacy, Peth Vadgaon, Kolhapur 416112. INDIA.

Ph no: 9823047380

E-mail: atulpharma@gmail.com 
ucts. These APIs eventually find their way into surface waters, ground waters, drinking waters, marine environments, sewage sludge and bio-solids, tissues of animals, and food chains. APIs affect both the abiotic and biotic systems. ${ }^{7,8}$ Drug usage in both the human and veterinary population is escalating day by day. According to one estimate, 100,000 tons of antimicrobials are consumed every year. ${ }^{9}$ According US Environmental Protection Agency, an erythromycin antibiotic and several estrogenic hormones used in drug formulations are now on the Drinking Water Contaminant Candidate List. ${ }^{10}$ In recognition to a report published in the Washington Times, samples of wastewater were collected from industrial areas in south India, where about majority of Indian drug factories dump their residues. It was found that enough of a single, powerful antibiotic like ciprofloxacin was being discharged $45 \mathrm{~kg}$ per day and also antibiotics lomiflxacin, oflxacin, norfloxacin, etc were detected at levels which are toxic even to plants and algae. Waste water downstream from the Indian plants contained 150 times highest levels than those detected in the United States of America. ${ }^{11}$

\section{Sources of Entry of Pharmaceuticals into Environment ${ }^{11-15}$}

Pharmaceutical chemicals can enter into the environment by a number of passage such as

- From low cost pharmaceutical production industries in developing countries such as India and China.

- Direct and improper disposal by patients/ humans by unused/expired medications in to the trash and through the excretion of urine or faeces.

- Release from hospital waste/trash

- Disposal by pharmacies

- Veterinary use as medicine as well as additives to animal food; which is excreted into soil or surface waters

- Dairy waste disposal

- Household water/sewage, solid garbage mix with drug surplus

- Leaching from defective landfills

- Release from aquaculture which has medicated feed, as well as excretion from the aquaculture

- Release from molecular farming/ pest control drugs

- Disposal of euthanized/medicated animal carcasses

- Even in many developing countries like India the physician samples which are given by companies to medical representatives for sales promotion purpose; Many times we read in local newspaper that such expired/unused drug products found across road side. ${ }^{16}$
Most common routes of pharmaceuticals entering the environment are shown in Figure 1.

\section{Impact of Improper Disposal}

Improper disposal may be hazardous if it leads to contamination of water supplies or local sources used by nearby communities or wildlife. Expired drugs may come into the hands of scavengers and children if a landfill is insecure. Pilfering from a stockpile of waste drugs or during sorting may result in expired drugs being diverted into the market for resale and misuse. Most of the expired pharmaceuticals are less efficacious and very few of them may develop a different adverse drug reaction profile. ${ }^{15}$ Pharmaceuticals and Personal Care Products (PPCP) have been found as pollutant in water and the environment. This poses a serious issue of ecological imbalance due to indiscriminate disposal of expired pharmaceutical products. ${ }^{14}$

Here are some of the examples of the impact of drugs through environment on human beings and animal. Evidence from rodent and fish study suggest that some endocrine-disrupting compounds, including those found in prescribed synthetic hormones, may contribute to tumour formation in humans. ${ }^{17} \mathrm{~A}$ large scale ecological disaster occurred in the Indian subcontinent was dramatic decrease in vulture population where vultures that fed on carcasses of cattle treated with diclofenac died from renal failure because they were unable to excrete the drug. ${ }^{18,19}$ Antibiotics in the sewage could increase selection pressure and promote the transfer of resistance genes from harmless environmental microbes into deadly pathogens, leading to emergence of deadly drug resistant microorganisms. Abnormal thyroid function, decreased fertility, decreased hatching success and alteration of immune function in birds and demasculinization and feminization of male fish has been linked to exposure to endocrine disrupting chemicals (EDCs) by-products of industrial waste. ${ }^{20,21}$ Some of the studies also tried to link the fall in sperm count in men that has decreased by $50 \%$ in 50 years. ${ }^{22}$ Not only the drugs but also the excipients used in the formulations affect the environment. ${ }^{23}$ In a study carried out by Cantrell $e t$ al. they measured the amounts of active ingredients in the medications which had expired 28-40 years ago, 12 of the 14 active ingredients persisted in concentrations that were $90 \%$ or greater of the amount indicated on the label and retained their full potency for 336 months or longer. ${ }^{24} \mathrm{~A}$ study carried out by Ramaswamy et al. showed that high levels of carbamazepine and triclosan were found in surface waters of Kaveri, Tamiraparani and Vellar rivers of Kerala. ${ }^{25}$ Hish levels $(31,000 \mu \mathrm{g} / \mathrm{L})$ of an antibiotic ciprofloxacin in a waste water treatment plant in Patancheru, India had been already 


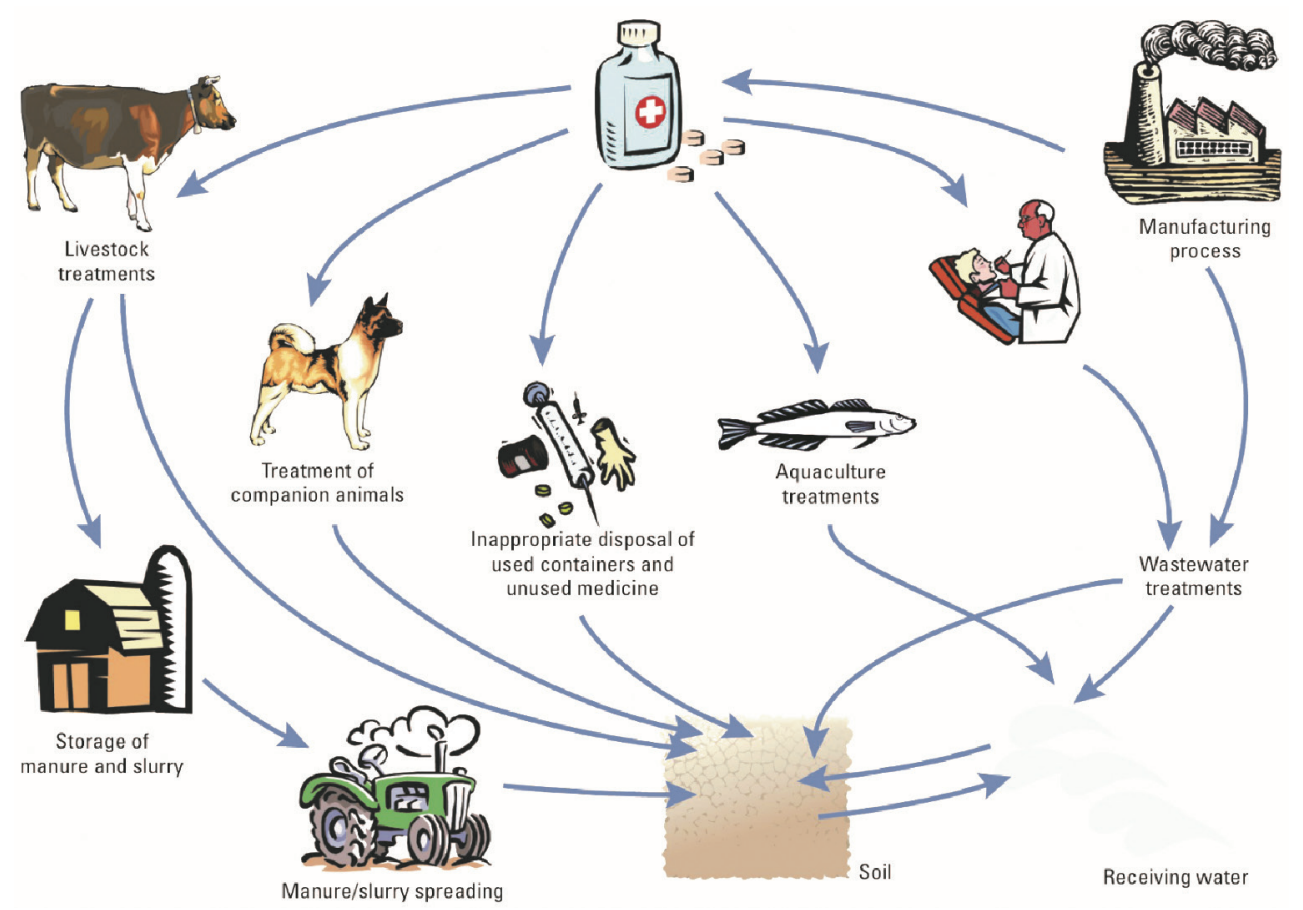

Figure 1: Routes of pharmaceuticals entering the environment 'Reproduced with the permission of Alistair Boxall.12

reported. ${ }^{13}$ India is reportedly breeding ground formost of multi-drug resistant microbes due to extensive usage and improper disposal of pharmaceutical drugs into the environment. ${ }^{26}$

All the above studies suggest that pharmaceutical drugs in India were well spread in several environmental as well as biological media. In addition to this, anti-neoplastic or cytotoxic drugs must be handled carefully as they have the ability to kill or stop the growth of living cells and can have extremely serious effects, such as interfering with reproductive processes in various life forms. ${ }^{27}$

\section{Cost of disposal}

The cost of drug disposal is higher than manufacturing and most of the people in Asian countries dump the waste materials in the earth, which is not good when considering the future. ${ }^{28}$ The cost of pharmaceutical waste disposal by high temperature incineration; in US cost, between $\$ 4.4$ million and $\$ 8.2$ million. $^{27}$ In India, cost of such disposal is about $0.5 \%$ to $2 \%$ of the total sales. ${ }^{29}$ Environmental hazards are responsible for an estimated $25 \%$ of the total burden of disease worldwide, and nearly 35\% in regions such as Sub-Saharan Africa. ${ }^{30,31}$ An extensive research project investigated a total of 123,761 incidents of measured environmental concentrations of pharmaceuticals around the world. ${ }^{32}$ It is evident that ever-increasing use of pharmaceuticals in clinical and veterinary practice can have adverse influence on the environment. ${ }^{33}$

\section{Disposal Methods and Remedial Measures}

Habits of medicine disposal depend on socioeconomic culture as well as regulatory guidelines, norms that prevail in the country. Most commonly used methods are throwing medicines in sinking, toilet and dustbins, which are environmentally unfriendly. Despite various complex variables that combine to cause pollution the most effective best management practices (BMPs) would address source reduction, namely, reducing the amount of medicine that goes unused. The Pharmaceutical Research and Manufacturers of America have evaluated unused medicine disposal options and have concluded that toilet flushing of unused medicine should be avoided whereas household trash disposal and take-back programs are effective to reduce their presence in the environment. An additional approach for a more environmentally sound handling of unused drugs is to use "social marketing". 17,33

Current FDA guidelines for the proper disposal of prescription drug recommend that unused/leftover/ expired medicines should not be flushed down the toilet or drain. Solid medications should be mixed with unappealing substances such as kitty litter or coffee grounds, put into a disposable container, and placed in the trash or disposed via community drug take-back programs. Liquid medicines should be mixed with salt, flour, charcoal, or nontoxic powdered spice, such as turmeric or mustard, to give the mixture an unappealing smell and texture. Medicines in blister packs should be wrapped in multiple layers of opaque tape, and then placed inside 
an opaque container for sealing. The lid of the medication bottle should be sealed with duct tape or packing tape, the medication bottle(s) should be placed inside a container that is not see-through and disposed off in the trash after sealing. ${ }^{34}$

There are various disposal methods which are described here and summarized in Table 1. ${ }^{27,29,34}$

- Take unused, unneeded, or expired prescription drugs out of their original containers and throw them in the trash.

- Mix the prescription drugs with an undesirable substance, like used coffee grounds or kitty litter. Putting them in impermeable, non-descript con- tainers, such as empty cans or sealable bags, will further ensure the drugs are not diverted.

- Throw these containers in the trash.

- Flush prescription drugs down the toilet only if the accompanying patient information specifically instructs doing so.

- Community drug take-back programs that allow the public to bring unused drugs to a central Location for proper disposal. Several countries like United States, Australia, British Columbia, and Sweden, "drug take back programme" achieving the goals. ${ }^{35}$ and need to implement these programs in developing countries like India and China which are the major centres for manufacture of pharmaceuticals.

\section{Table 1: Summary of disposal methods in and after emergencies ${ }^{27,29,34}$}

\begin{tabular}{|c|c|c|}
\hline Disposal methods & Types of pharmaceutical & Comments \\
\hline $\begin{array}{l}\text { Return to donor or } \\
\text { manufacturer, trans frontier } \\
\text { transfer for disposal }\end{array}$ & $\begin{array}{l}\text { All bulk waste pharmaceuticals, particularly } \\
\text { antineoplastics. }\end{array}$ & $\begin{array}{l}\text { Usually not practical-transfrontier } \\
\text { procedures } \\
\text { may be time consuming }\end{array}$ \\
\hline $\begin{array}{l}\text { High temperature incineration with } \\
\text { temperatures greatly in } \\
\text { excess of } 1200^{\circ} \mathrm{C}\end{array}$ & $\begin{array}{l}\text { Solids, semisolids, powders, } \\
\text { Antineoplastics, controlled substances. }\end{array}$ & Expensive. \\
\hline $\begin{array}{l}\text { Medium temperature Incineration with } \\
\text { two-chamber incinerator with minimum } \\
\text { temperature of } 850^{\circ} \mathrm{C} \text {. Cement kiln } \\
\text { incineration }\end{array}$ & $\begin{array}{c}\text { In the absence of high temperature } \\
\text { Incinerators, solids, semi-solids, powders. } \\
\text { Controlled substances. }\end{array}$ & $\begin{array}{l}\text { Antineoplastics best incinerated at } \\
\text { high temperature. }\end{array}$ \\
\hline \multicolumn{3}{|c|}{ Immobilization } \\
\hline Waste encapsulation & $\begin{array}{l}\text { Solids, semi-solids, powders, liquids, } \\
\text { antineoplastic, controlled substances. }\end{array}$ & \\
\hline Inertization & $\begin{array}{l}\text { Solids, semi-solids, powders, } \\
\text { Antineoplastic, controlled substances. }\end{array}$ & \\
\hline \multicolumn{3}{|c|}{ Landfill } \\
\hline $\begin{array}{l}\text { Highly engineered sanitary } \\
\text { landfill }\end{array}$ & $\begin{array}{l}\text { Limited quantities of untreated solids, semi-solids } \\
\text { and powders. Disposal of waste pharmaceuticals } \\
\text { after }\end{array}$ & \\
\hline Engineered landfill plastics. & $\begin{array}{l}\text { Waste solids, semi-solids and powders, preferably } \\
\text { after immobilization. PVC }\end{array}$ & \\
\hline Open uncontrolled non engineered dump & $\begin{array}{l}\text { As last resort untreated solids, semisolids, } \\
\text { powders-must be covered immediately with } \\
\text { municipal waste. Immobilization of solids, semi- } \\
\text { solids, powders is preferable. }\end{array}$ & $\begin{array}{l}\text { Not for untreated } \\
\text { Controlled substances. }\end{array}$ \\
\hline Sewer & $\begin{array}{l}\text { Diluted liquids, syrups, intravenous fluids, small } \\
\text { quantities of diluted disinfectants (supervised). }\end{array}$ & $\begin{array}{l}\text { Antineoplastics, and } \\
\text { undiluted disinfectants } \\
\text { and antiseptics not } \\
\text { recommended }\end{array}$ \\
\hline Fast-flowing watercourse & $\begin{array}{l}\text { Diluted liquids, syrups, intravenous } \\
\text { fluids; small quantities of diluted } \\
\text { Disinfectants (supervised). }\end{array}$ & $\begin{array}{l}\text { Antineoplastics, and } \\
\text { undiluted disinfectants } \\
\text { and antiseptics not } \\
\text { Recommended. }\end{array}$ \\
\hline Burning in open containers & $\begin{array}{l}\text { As last resort, packaging, paper, } \\
\text { Cardboard. }\end{array}$ & $\begin{array}{l}\text { Not acceptable for PVC } \\
\text { plastics or } \\
\text { Pharmaceuticals. }\end{array}$ \\
\hline Chemical decomposition & $\begin{array}{l}\text { Not recommended unless special chemical } \\
\text { expertise and materials available. }\end{array}$ & $\begin{array}{l}\text { Not practical for quantities over } \\
\qquad 50 \mathrm{~kg} .\end{array}$ \\
\hline
\end{tabular}




\section{Table 2: Methods of disposal of various pharmaceutical dosage form}

\section{Tablets Capsules}

Up to 50 tablets or capsules soak in about $100 \mathrm{ml}$ of water and collect the same in a polyethylene bag containing used Tea/Coffee grind. Seal the bag and put in trash. Big quantity-Pulverize using heavy duty crusher. Collect in a poly bag and seal. Dispose it in high temperature incinerator (Temp. $850^{\circ} \mathrm{C}$ to $1200^{\circ} \mathrm{C}$ )/approved site for solid waste disposal by the Pollution Control Board of the State.

\section{Injectables ampoules/vials:}

Up to 50 Injectables-ampoules/vials: Ampoules/Vials (up to $10 \mathrm{ml}$ )-break ampoules/ open vials and collect liquid in a polyethylene bag containing used Tea/Coffee grind. Seal the bag and put in trash. For bigger quantities, use heavy duty crusher to separate liquid and dilute it with water and transfer it to Effluent Treatment Plant (ETP) of the manufacturing unit. Broken glass/vials (after removal of label), rubber stoppers and seals should be disposed off as scrap. Powder Injectables (in Vials/Ampoules) to be disposed off in an incinerator as indicated above.

\section{Oral liquids and Intravenous fluids}

Small quantity-Dilute the liquid with water and drain it. For bigger quantity, dilute collected liquid with water and transfer it to ETP of the manufacturing unit. Liquids with high solid contents to be disposed off in an incinerator as indicated above.

\section{Semi solids:}

Small quantity, mix it with used Tea/Coffee grind in a polyethylene bag. Seal the bag and put in a trash. De-shape the containers/remove the label and discard the containers. Semisolids in bigger quantity to be disposed off in an incinerator mentioned earlier. ContainersTubes to be de-shaped and remove the label from glass/plastic container before disposal as a scrap.

\section{Anti-infectives- $\beta$-lactams:}

Small quantity of all $\beta$-lactam antibiotics to be destroyed by soaking in $1 \mathrm{~N}$ Sodium Hydroxide for 30 mins or $1 \%$ Hydroxylamine in Water for 10 mins and trash. Bigger quantity to be disposed off in an incinerator (Temp. $850^{\circ} \mathrm{C}$ to $\left.1200^{\circ} \mathrm{C}\right)$ indicated above.

\section{Anti-infectives-others:}

Tetracyclines-Small quantity to be soaked in $10 \%$ of Calcium Hydroxide/any other Calcium salt in Water for 30 mins and trash. Macrolides(Erythromycin, Clarithromycin etc.)-Small quantity, soak in 1N Hydrochloric Acid and trash. Amino glycosides (Gentamycin, Amikacin etc.)-Small quantity dilute with large volume of water and drain it. Bigger quantity of all the above anti-infective should be disposed of in an incinerator as mentioned above.

\section{Steroids:}

Small quantity-Soak in $1 \mathrm{~N}$ Sodium Hydroxide for 30 mins and trash. Bigger quantity-all dosage forms (taken out from the primary packing materials) to be incinerated at the temperature range indicated above.

\section{Hormones:}

Small quantity-Aqueous solution to be exposed to UV for 20 minutes and trash. Estrogens-small quantity in aqueous solution should be exposed to ultrasound at 0.6 and $2 \mathrm{kw}$ in a sonicator for $60 \mathrm{mins}$. and trash. Bigger quantity-all solid dosage forms (taken out from primary packaging materials) to be incinerated as indicated above.

\section{Disinfectants:}

Small quantity-use it. Bigger quantity-Not more than 50L. Dilute with enough quantity of water to ensure dilution with loss of activity and drain it in ETP.

\section{Controlled substances:}

Small quantity-Flush down the toilet to avoid misuse. Bigger quantity-All dosage forms (take out from primary packaging material) to be incinerated as mentioned above.

\section{Reuse of Expired Pharmaceutical Products:}

In the event of Emergency situation, Regulatory Agencies do allow Revalidation, after Analysis of Expired Pharmaceutical Drug Products, if found satisfactory, for Human/Animal consumption.

\section{Education and Training}

Continuing education and training at every level is desirable to generate awareness of hazards associated with indiscriminate Disposal of unused/expired pharmaceutical products-an emerging environmental issue.

Take Back Programme by company

The expired products are taken from retailer by wholesaler and then to company need to be implement effectively and efficiently.

\section{Precaution to be taken at the time of disposal ${ }^{27,29}$}

- Contamination of drinking water must be avoided. Landfills must be sited and constructed in a way that minimizes the possibility of leaching entering a ground water, surface water or drinking water system.

- Non-biodegradable antibiotics, antineoplastics and disinfectants should not be disposed into the sewage system as they may kill bacteria necessary for the treatment of sewage. Antineoplastics should not be flushed into watercourses as they may damage aquatic life or contaminate drinking water. Similarly, large quantities of disinfectants should not be discharged into a sewage system or watercourse. They can be introduced if well diluted.

- Burning pharmaceuticals at low temperatures or in open containers results in release of toxic pollutants into the air. Ideally this should be avoided.

- Inefficient and insecure sorting and disposal may allow drugs beyond their expiry date to be diverted 
for resale to the general public. In some countries scavenging in unprotected insecure landfills is a hazard.

- In the absence of suitable disposal sites and qualified personnel to supervise disposal, unwanted pharmaceuticals present no risk, provided they are securely stored in dry conditions. If stored in their original packing there is a risk of diversion and to avoid this they are best stored in drums with the pharmaceuticals immobilized.

As per National formulary of India, Methods of disposal of various pharmaceutical dosage forms are summarized here in Table $2{ }^{14}$

\section{Role of Pharmacist}

There is evidence that pharmacists should accept a degree of responsibility for changing the entire medication-use process so as to minimize the environmental effects of pharmaceuticals. The entire process of prescribing, dispensing, pharmaceutical care, disposal of unused medication and ultimately reduction in metabolic waste discharge into the environment. ${ }^{36}$ The pharmacist practitioner has the opportunity to influence more rational prescribing that would reduce the amount of leftover medicines. This would decrease potential risks to the environment as well. Being respected, trusted and most accessible drug information resources, pharmacists are in the forefront of tackling issues of prudent drug disposal methods to end users of drugs.

All pharmacists should familiarize themselves with their region's drug disposal activities and be able to recommend them to their patients. If we look at Indian scenario fundamental changes in pharmaceutical education are need of the hour; curriculum restructuring should include dissemination of knowledge about proper drug disposal; environmental aspects of medication, use in their practice curriculum provides a good basic understanding of medicines metabolism and toxicology which can help to provide an understanding of how medicines and related substances can react in nature and what environmental effects they might have which is currently not in many universities syllabus in India. ${ }^{37}$ The implementation of effective eco-friendly approaches for pharmaceuticals and health-care waste management programmes require multi-sectorial cooperation and interaction at all levels. There is a great opportunity for the profession and the pharmacist practitioner to provide substantial leadership in the resolution of the environmental issues that surround medication use. ${ }^{36}$ Proper patient counselling on safe medication disposal can make a significant difference to public health and environment, which has proved in few studies.38,39 Continuing education and training at every level is desirable to generate awareness of hazards associated with indiscriminate disposal of unused/expired pharmaceutical products-an emerging environmental issue. ${ }^{29}$

\section{CONCLUSION}

Medication disposal is alarming issue today and gaining more and more awareness from the healthcare professionals as well as consumers. Pharmacist has the potential to be on the forefront of this movement as healthcare professional and pharmacist are in admirable position to educate patient about safe drugs disposal. Proper patient counselling on safe medication disposal can make a significant difference to public health and environment. A practical approach should be there to incorporate this important issue in the curriculum as the need of the hour. Also establishment of cost-effective and acceptable government-run collection and disposal systems is necessary. There should be some norms and stringent guidelines for same. Careful and proper disposal of medications can help to decrease environmental load of drugs. All multidisciplinary stake holders, government, NGOs, physician, pharmacist, patient, and public should work together hand in hand to reduce burden of unused and expired medicine on ecosystem. Proper waste management strategy is needed to ensure health and environmental safety.

\section{ACKNOWLEDGEMENT}

The authors would like to thank Alistair Boxall. For giving permission to reproduce figure.

\section{CONFLICT OF INTEREST}

The author declare no conflict of interest.

\section{ABBREVIATION USED}

\section{US: United States}

API: Active Pharmaceutical Ingredient

PPCP: Pharmaceuticals and Personal Care Produc

EDCs: Endocrine Disrupting Chemicals

BMPs: Best Management Practices

FDA: Food and Drug Administration

PVC: Polyvinyl Chloride

ETP: Effluent Treatment Plant

\section{REFERENCES}

1. Ternes TA. Occurrence of drugs in German sewage treatment plants and rivers. Water Res. 1998;32(11):3245-68. 
2. Fram MS, Kenneth B. Occurrence and concentrations of pharmaceutical compounds in groundwater used for public drinking-water supply in California. Science of The Total Environment. 2011;409(18):3409-17.

3. Scenario of pharmaceutical market in India. Available from http://www. smetimes.in/smetimes/in-depth/2013/May/27/scenario-of-pharmaceuticalmarket-in-india629370.htmlaccessed on 21 February 2015.

4. Seeheusen DA, Edwards J. Patient practices and beliefs concerning disposal of medications. Am Board Fam Med. 2006;19(6):542-7.

5. Over 1 million tones medical waste headache for India. Available from: http:// www.thepharmatimes.in/./237-over-1-million-tonnes-medicalwaste-he. Last cited on 2014 Apr 15.

6. Current Good Manufacturing Practice In Manufacturing, Processing, Packing, Or Holding Of Drugs; General available from http://www.accessdata.fda.gov/ scripts/cdrh/cfdocs/cfcfr/cfrsearch.cfm?fr=210.3Cited on 2015 November 2.

7. Kummerer K. Pharmaceuticals in the environment. Annu Rev Environ Resour. 2010; 35(1)57-75.

8. Verma R, Seth GL, Bihani D. Pharmaceutical waste/scrap management. Available from www.pharmatutor.org/articles/pharmaceutics?page=17. Cited on 2014 March 2.

9. Wise R. Antimicrobial resistance: Priorities of action. J Antimicrob Chemother. 2002;49(4):585-6.

10. U.S. EPA (U.S. Environmental Protection Agency) Drinking Water Contaminant Candidate List Available From: http://www.epa.gov/safewater/ccl/ccl3. htmlAccessed 15 Jan 2015.

11. World's highest drug levels entering India stream. The Washington Times. 2009 Jan 26; Available From: http://www.washingtontimes.com/news/2009/jan/26/ worlds-highest-drug-levels-entering-india-stream/?page=all Accessed $15 \mathrm{Jan}$ 2015.

12. Boxall, Alistair. The environmental side effects of medication. EMBO reports. 2004;5(12)1110-6.

13. Senthil KK. Pharmaceutical Substances in India are a Point of Great Concern? Hydrol Current Res. 2012;3(5)1-3.

14. National Formulary of India. $4^{\text {th }}$ ed. India: Government of India, Ministry of Health and Family Welfare, Indian Pharmacopoeia Commission; 2010.

15. Akter N. Medical waste management: a review. Environmental Engineering Program, School of Environment, Resources and Development Asian Institute of Technology, Thailand. 2000:1-25.

16. Expired drugs worth lakhs found dumped in Azamgarh Times of India $31^{\text {st }}$ December 2014. Available from: http://timesofindia.indiatimes.com/ city/varanasi/Expired-drugs-worth-lakhs-found-dumped-in-Azamgarh/ articleshow/45709904.cms (Accessed on Jan 2, 2015).

17. Rodriguez-Mozaz S, Weinberg HS. Meeting Report: Pharmaceuticals in WaterAn Interdisciplinary Approach to a Public Health Challenge. Environmental Health Perspectives. 2010;118(7):1016-20.

18. Daughton CG. Drugs and the Environment: Stewardship and sustainability. National Exposure research laboratory, Environmental Sciences Division, US EPA, Las Vegas, Nevada, report NERL-LV-ESD 10/081,EPA/600//R-10/106, 12 Sept 2010, 196pp.Available from www.epa.gov/nerlesd1/bios/daughton/ APM200-2010.pdf Cited on 2015 Jan 3.

19. Oaks JL, Gilbert M, Virani MZ, Watson RT, Meteyer CU, Rideout BA. Diclofenac residues as the cause of vulture population decline in Pakistan. Nature. 2004;427(6975):630-3.

20. Colborn T, Vomsaal FS, Soto AM. Developmental effects of endocrine disrupting chemicals in wildlife and humans. Environ Health Perspect. 1993;101(5):378-84.
21. Kvarnryda M, Grabicb R, Brandta I, Berg C. Early life progestin exposure causes arrested oocyte development, oviductal agenesis and sterility in adult Xenopustropicalis frogs. AquatToxicol. 2011;103(1):18-24.

22. Carlsen E, Giwercman A, Keiding N, Skakkebaek NE. Evidence for decreasing quality of semen during past 50 years. BMJ. 1992;305(6854):609-13.

23. Medhi B, Sewal RK. Ecopharmacovigilance: An issue urgently to be addressed. Indian Journal of Pharmacology. 2012;44(5):547-9.

24. Cantrell L, Suchard JR, Wu A, Gerona RR. Stability of active ingredients in long-expired prescription medications. Arch Intern Med. 2012;172(21): 1685-7.

25. Ramaswamy BR, Shanmugam G, Velu G, Rengarajan B, Larsson DG. GCMS analysis and ecotoxicological risk assessment of triclosan, carbamazepine and parabens in Indian rivers. J Hazard Mater. 2011;186(2):1586-93.

26. Gale J, Narayan A. Drug-defying germs from India speed post-Antibiotic Era. Bloomberg Markets Magazine. 7May Available From: http://www.bloomberg. com/news/2012-05-07/drug-defying-germs-from-india-speed-post-antibiotic-era. htm Accessed on 2015 Feb 2.

27. World Health Organization. Guidelines for Safe Disposal of Unwanted Pharmaceuticals in and after Emergencies1999. Available from: http:// www.who. int/water_sanitation_health/medicalwaste/unwantpharm.pdf Last accessed on 2014 Feb 01.

28. Parasuraman S. Environmental Safety-Breath for Next Generation. Journal of young Pharmacist. 2015;7(2):61-2.

29. Office of National Drug Control Policy. Proper disposal of prescription drugs. February 2007.http://www.whitehousedrugpolicy.gov/publications/pdf/prescrip_ disposal.pdf Accessed Jan 20,2014.

30. World Health Organization. Health and environment in sustainable development: Five years after the Earth Summit: Executive Summary. 1997.

31. Smith KR, Corvalán CF, Kjellstrom T. How much global ill health is attributable to environmental factors?. Epidemiology-Baltimore. 1999;10(5):573-84.

32. BIO Intelligence Service. Study on the environmental risks of medicinal products, Final Report prepared for Executive Agency for Health and Consumers. 2013.

33. Newton-Ward M. Appendix: social marketing resources. In: Kotler P, Lee N, editors. Social Marketing: Influencing Behaviors for Good. Thousand Oaks, CA: Sage; 2007. pp. 395-402.

34. How to dispose of unused medicines. FDA Consumer Health Information. Available from: http://www.fda.gov/for consumers/consumer updates/ ucm101653.htm. Last cited on 2014 Mar 23.

35. Habitats and Ecosystems. Available from: www.iisgcp. org/unwanted meds, Accessed Jan 20,2014.

36. Green Pharmacy Practice Report for Pharmacist http://www.fip.org/ bangkok2014/files/static/Draft_document_GREEN_PHARMACY_PRACTICE. pdfLast accessed on 2015 Feb 19.

37. Yang TH, Scolaro KL, Dinkins MM. Raising awareness of medication disposal in professional schools. J Am Pharm Assoc. 2010;50(4):444.

38. Abrons J, Vadala T, Miller S, Cerulli J. Encouraging safe medication disposal through student pharmacist intervention. J Am Pharm Assoc. 2010;50(2):169-73.

39. P. Rushbrook E, Pugh MP, Solid waste landfills in middle and low income countries: a technical guide to planning, design and operation. (Jointly produced by the WHO Regional Office for Europe, World Bank, Swiss Development Corporation (SDC), and Swiss Centre for Development Cooperation InTechnology and Management (SKAT)). Washington DC: World Bank; 1999. 